\title{
Statyba
}

\section{EVALUATION OF DEFECTS IN BUILDINGS}

\section{A. Janickas}

To cite this article: A. Janickas (1998) EVALUATION OF DEFECTS IN BUILDINGS, Statyba, 4:1, 12-19, DOI: 10.1080/13921525.1998.10531374

To link to this article: https://doi.org/10.1080/13921525.1998.10531374

册 Published online: 26 Jul 2012.

Submit your article to this journal

III Article views: 94 


\section{PASTATU DEFEKTINGUMO VERTINIMAS}

\section{A. Janickas}

\section{1. İžanga}

Naujos statybos ir esamy gyvenamuju pastaty eksploatavimo būsimos situacijos vertinimas rodo aiškų dèsningumą - absoliutu ir santykini remonto išlaidụ augimą didejant gyvenamojo fondo apimčiai. Naujo būsto statybai tenkanti dalis iš bendrosios statybos ir remonto produkcijos vertes ateityje smarkiai mažès, o būsto remontui ir eksploatavimui - didès. Prognozuojama, kad šimtmečio pabaigoje gyvenamojo fondo remonto išlaidos susilygins su kapitaliniц ìdèjinių apimtimi, o darbo sąnaudos du ir daugiau kartụ viršys naujos statybos darbo sąnaudas.

Konkretaus pastato bedefektè būklè, atitinkanti stiprio ir deformatyvumo skaičiavimo reikalavimus, nèra pastovi ir eksploatavimo laikotarpiu gali kisti tiek teigiama, tiek neigiama kryptimi. Gyvenamojo namo bedefektès būklès kaip sudètingos techninès sistemos sąvoka daug platesnè, negu jo elementu ir paprastu sistemų, galinčiụ būti tik dviejụ būsenų: darbinès ir nedarbinès.

Gedimas - tai ịvykis, per kuri gaminys visiškai arba iš dalies nebetinka naudoti, kai nors vienas pagrindinis parametras, jvertinantis gaminio kokybę, išeina už nustatytụ nukrypimu ribos [1]. Taigi gedimas yra tokios ribinès būsenos susidarymas, kai gaminys visiškai arba iš dalies netenka savo kokybès, efektyvumo. Tai suteikia galimybę bendriausia forma nagrinèti gedimą kaip atsitiktinị iškritimą iš leistinos kokybès erdvés.

\section{Gedimų ir pažeidimų atsiradimo priežastys}

Konstrukcijų bei inžinerinių sistemų gedimai gali atsirasti dèl tokių veiksnių: 1) konstrukcijų gamybos ir statybos; 2) korozijos; 3) perkrovos; 4) mechaniniu ir fiziniu poveikių; 5) pagrindu deformacijų; 6) kitu poveikių. Šie veiksniai pasireiškia, o kartu ir konstrukcijy bei inžinerinių sistemu gedimai atsiranda dažniausiai dèl tokių priežasčių: 1) blogos gamybos ir statybos darbų kokybès; 2) netinkamos pastatu eksploatacijos; 3) projektavimo klaidų; 4) kitų priežasčiu.

Ribinè būsena - objekto būsena, kai jo tolesnis eksploatavimas turi būti nutrauktas dèl nepašalinamo darbo saugos reikalavimų pažeidimo arba nepašalinamo nustatytu parametry nukrypimy už nustatytų ribų, arba nepašalinamo eksploatacijos efektyvumo sumažèjimo žemiau leidžiamų reikšmių, arba būtinumo atlikti kapitalinị remontą [2].

Remontuojamy̨ objekty ribinès būsenos susidarymas nustatomas momentu, kai tolesnis eksploatavimas negalimas arba netikslingas esant vienai ar kelioms priežastims:

- negalima užtikrinti saugos, be gedimų arba efektyvios eksploatacijos minimaliai leistinu lygiu;

- dèl susidevejjimo ir (arba) senejimo objektas tapo tokios būsenos, kai remontui reikalingos neleistinai didelès išlaidos arba neužtikrinamas būtinas atkuriamo darbingumo ir tinkamumo lygis.

Pastato normalios būklès pažeidimus suprantame, viena vertus, kaip pažeidimus, neliečiančius pagrindinès konstrukcinès schemos (didesnè drègmé, medžiagu savybių pakitimai, apdailos pažeidimai ir kt.), o kita vertus, - kaip pagrindinès konstrukcinès schemos pažeidimus (elementų skerspjūvio susilpnèjimas, laikančiuju konstrukciju deformacijos ir t.t.). Dabartiniu metu pripažinta, kad ne tik ịvairios apkrovos ir poveikiai, bet ir pastatų bei statinių sistemų fizinès ir geometrinès charakteristikos laikomos atsitiktiniais dydžiais [2]. Suirimų ir gedimu atsiradimų laikas ir vieta, darbo be gedimy trukmé, gyvavimo trukmè gyvavimo trukmé iki pirmo einamojo arba kapitalinio remonto, tolesnis gedimy ir atstatymo srautas, bendras sistemos (elemento) ir gyvenamuju namu naudojimo laikas apskritai, patikimumo didinimo ekonominis efektas ir t.t. taip pat laikomi atsitiktiniais dydžiais, t.y. tokiais, kuriems turint praktini patyrimą parenkamos vienokios ar kitokios reikšmès, tačiau iš anksto nežinoma kokios. 


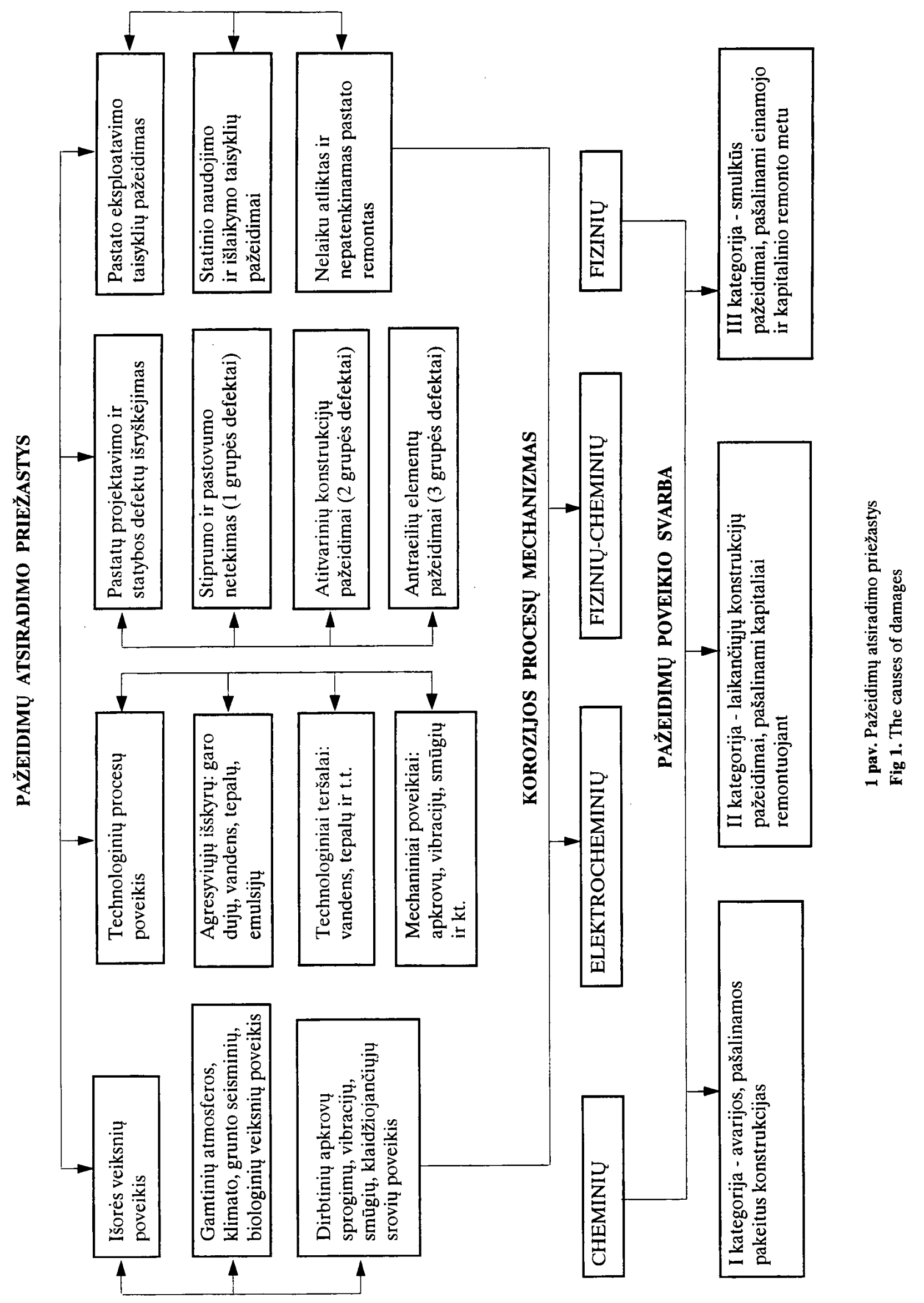


Didelè pastatų ir statinių gedimų dalis yra mechanines prigimties - stiprio, standumo, pastovumo netekimas, plyšiu atsivèrimas už leistinu ribų ir kt. Pagal parametrų kitimo pobūdị skiriami staigūs (katastrofiniai) gedimai, atsirandantys parametrų šuoliškais pokyčiais (trapus suirimas, sluoksnio atplyšimo suirimas, sulüžimas ir t.t.) ir laipsniškais (parametriniais) gedimais, letai kintant vienam ar keliems parametrams (elementų ir visos sistemos senejimas ir (arba) susidèvejimas veikiant apkrovoms ir poveikiams) [2].

\section{Eksploatavimo sąlygu įtaka konstrukcijų ir sistemų gedimams}

Literatūros šaltinių duomenimis [2], pastatų konstrukcijų bei inžineriniụ sistemu gedimai labai susiję su remonto ir išlaikymo išlaidomis. Tai pavaizduota 2 pav. grafike.

Paprastai, konstrukcijoms senėjant palaipsniui blogèja ju kokybè, ir bedefekčio darbo $P(t)$ tikimybè yra mažejanti laiko $t$ funkcija.

Eksploatavimo pradžioje (įdirbio periodu) gedimai atsiranda dažniau nei darbo periodu. Šiuo laikotarpiu intensyviai atsiranda staigūs gedimai, kaip paslepti ir aiškūs statybinių gaminių ir ịrengimų defektai, skirtingu medžiagu ir pačių statybos bei montavimo darby žema kokybé ir kt. Jau pirmaisiais pastaty ir statiniy funkcionavimo metais reikalingos papildomos léšos neplaniniam remontui ir net atskirụ elementụ keitimui.

Antrasis periodas, vadinamas normalios eksploatacijos periodu, yra pagrindinis, jis gali tęstis keletą dešimtmečiụ. Šiuo laikotarpiu staigūs (netikèti) gedimai lygiais laiko tarpais pasireiškia palyginti vienodai $[2,3]$. Gedimų srautas kažkuriuo laiko tarpu pasiskirsto eksponentiniu désniu su parametru, lygiu gedimu srauto parametrui

$$
P(t)=e^{-\frac{t}{\bar{t}}}=e^{-n \lambda t} .
$$

Čia $P(t)$ - darbo be gedimy tikimybé laikotarpiu $t ; t$ darbo trukme, skaičiuojama nuo stebejimu pradžios, metais, menesiais ir kt.; $\bar{t}$ - maksimalus darbo laikas iki gedimo; $e=2,718$ - natūraliụjų logaritmų pagrindai; $n$ - elementų skaičius; $\lambda$ - pasiskirstymo parametras; $t=\frac{1}{n \cdot \lambda}$ - vidutinis elemento bedefekčio darbo laikas (darbo laikas iki gedimo).

Netikèti gedimai, būdingi gaminio normalaus eksploatavimo periodu, yra tokiy atsitiktines prigim- ties skirtingu priežasčiu sąveikos rezultatas: perkrovos, aiškių gaminių pažeidimų, gamybinès ir statybinès gamybos paslèptų defektụ ir kt. Netikètų gedimų prognozuoti negalima, todèl numatyti planines priemones netikètiems gedimams likviduoti nèra prasmès [2].
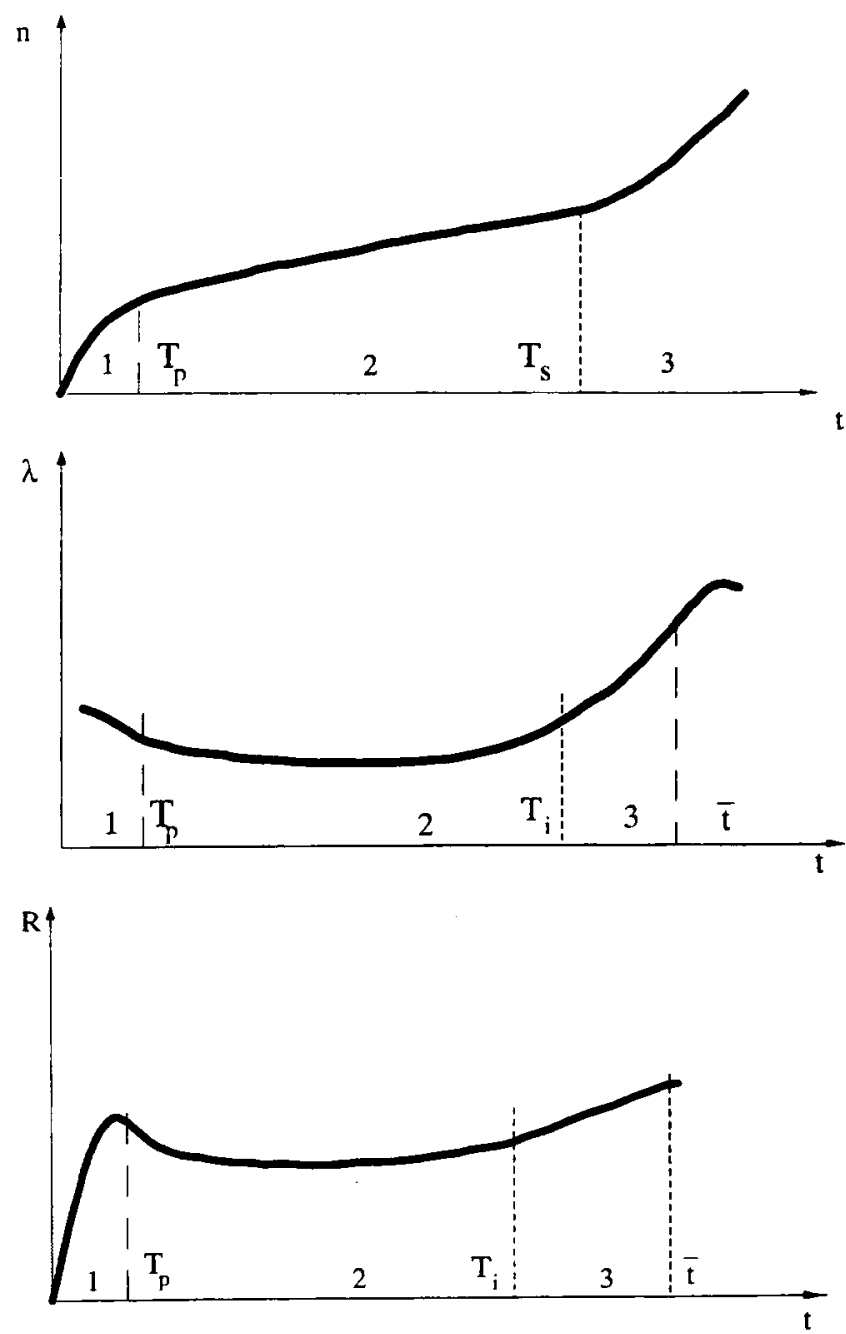

2 pav. Gedimų ir išlaidų jiems šalinti pasiskirstymo pobūdis, atsižvelgiant i eksploatavimo trukmę:
a - gedimo didejimo pobūdis,
b - gedimų srauto kitimas;
c - gedimų pašalinimui reikalingos išlaidos; n - gedimu skaičius;
$\lambda$ - gedimu srauto parametras;
$\mathrm{R}$ - išlaidos;
$\mathrm{t}$ - vidutine gyvavimo trukmé

Fig 2. Distribution of damages and expenses for removing them according to the service duration

a) character of damage development;

b) change of stream of damages;

c) expenses for removing damages; $\mathrm{n}$ - number of damages;

$\lambda$ - parameter of stream of damages;

$\mathrm{R}$ - expenses;

$t$ - average service time 
Trečiuoju periodu pastato naudojimo trukmè pasiekia $T_{s}$ (susidévèjimo periodas), prasideda susidevejjimas. Nuo šio momento masiškai pasireiškia senéjimo ir susidèvejimo procesas, gedimu, ypač palaipsnių, srautas pradeda augti, atitinkamai dideja ir remonto bei išlaikymo išlaidos (žr. 2 pav.).

Šiuo periodu poveiksmis pasireiškia skirtingai [3]. Pirmiausia padideja gedimu intensyvumas. Antra, sugedus vienam elementui beveik vienu metu yra gedimų tikimybé jų priklausomuose elementuose. Trečia, vieno iš elementu gedimas gali daryti ịtaką kitu sistemos elementu darbo režimo pokyčiams, tai padidina jų gedimo tikimybę ateityje. Ketvirta, sugedusių elementu pakeitimas naujais nulemia, kad kito gedimo greičiausiai galima laukti elementuose, kurie buvo pakeisti anksčiau, bet ne ką tik pakeistame.

Gyvenamujjų pastatų patikimumui užtikrinti, remonto metodams ir profilaktikos sistemai rengti būtina konstrukciju, elementu, mazgu ir sujungimų techninès būklès objektyvi informacija. Konkretūs jos uždaviniai susiję su ankstyvu konstrukciju ir defektų bei pažeidimụ suradimu, techninès apžiūros ir remonto procesų optimizavimu, pažeidimụ priežasčių ir remonto darbụ apimties nustatymu.

Gaunami statistikos duomenys turi būti sukoreguoti atsižvelgiant i eksploatavimo sąlygas, kurios skaičiuojant įvertinamos eksploatavimo sąlygu koeficientu. Daugumos eksploatacinių veiksnių neįmanoma gauti laboratorijos sąlygomis, juos galima tyrinèti tik eksploatuojamuose statiniuose, todè eksploatavimo sąlygu koeficientams nustatyti naudojami statistiniai metodai. Keleto veiksniu ịtakos konstrukcijų būklei nustatyti reikalingus atitinkamus koeficientus galima gauti varijuojant vieno veiksnio reikšmes nuo maksimumo iki minimumo, paliekant visų kitu veiksniu vidutines reikšmes. $\mathrm{K}_{\mathrm{f}}$ reikšmę galima nustatyti kiekvienam veiksniui, turint konstrukcijos būklès pagal tris veiksnius lygti

$$
y=a_{0}+a_{1} x_{1}+a_{2} x_{2}+a_{3} x_{3} .
$$

Čia $y$ - rodiklis, apibūdinantis konstrukcijos a būklę; $x_{1}$, $x_{2}, x_{3}$ - veiksniai, turintys ịtakos konstrukcijos būklei.

Komplekso veiksnių įtakos konstrukciju būklès ivertinimui vienu metu veikiant keletui veiksnių, tikslinga naudoti daugelio veiksniu regresinę analizę, kuri leidžia gauti priklausomybę ir nustatyti kiekvieno veiksnio svarbą.

Aktualiausias gyvenamojo fondo eksploatavimo klausimas yra atskirų konstrukcijų ir elementų nepati- kimumo išaiškinimas, kada jų vidutinis faktinis (statistinis) įdirbis iki remonto $t_{\mathrm{f}}$ mažesnis už normuojamojo tarpremontinio resurso $t$ reikšmę, t.y. $t_{f}<t$.

Dydị $\mathrm{t}_{\mathrm{f}}$ galima apskaičiuoti taip:

$$
t_{f}=t \cdot K_{r}(t)
$$

Čia $t$ - tarpremontinio resurso, nustatyto tam tikrai konstrukcijai arba jos elementams, dydis; $K_{r}$ - tam tikru konstrukcijų detalių nustatyto resurso $t$ panaudojimo statistinis koeficientas.

Koeficiento $K_{r}(t)$ reikšmès apskaičiuojamos pastatụ konstrukciju ir detalių eksploatavimo statistikos duomenų pagrindu.

$$
K_{r}(t)=\frac{\left[N_{0}-n(t) t\right] \sum_{n(t)}^{i=1} t_{i}}{N_{0} t} .
$$

Čia $N_{0}$ - pradinis pastato detalių ir konstrukciju skaičius, imamas eksploatacinèms patikimumo charakteristikoms apskaičiuoti; $n(t)$ - suminis konstrukciju, pirma laiko sugedusiu nustatyto resurso laikotarpiu $t$, skaičius; $t_{i}$ - įdirbis iki sugedimo $i$-osios sugedusios konstrukcijos, dirbant nustatyto resurso t laikotarpiu.

\section{Ryšys tarp konstrucijų susidévëjimo ir patikimumo}

Fizinio susidevejimo laipsnis - tai kiekybinis techninès būkles ịvertinimas, rodantis nuostolių dalị, juos lyginant su konstrukcijy techniniy ir eksploatacinių savybių pirmine būkle, eksploatavimo periodu. Šie nuostoliai gali būti išreikšti taip pat visos konstrukcijos arba pastato pradines vertès sumažejimu. Taip vertinant konstrukcijų techninę būklę galimas ju palyginimas, nežiūrint ju skirtingu savybių ir ypatybiụ.

Susidèvejimo prognozavimas - sudetingas daugelio faktoriy uždavinys. Kadangi statiniuose yra didžiulis kiekis ịvairaus stiprumo konstrukcijų ir medžiagu su skirtinga gyvavimo trukme, nerealu prognozuoti visą jo gyvavimo trukmę kaip visų pastato elementu gyvavimo trukmiu derini.

Statybos medžiagas ir konstrukcijas galima skirstyti ị keturias ilgaamžiškumo grupes: trumpo (apdailos medžiagos), vidutinio (apdailos medžiagos, inžinerinès sistemos, aplinkos sutvarkymas), didelio (inžinerinès sistemos, staliu darbai), labai didelio (laikančiosios konstrukcijos, sienos, pamatai, perdangos).

Tos pačios medžiagos, panaudotos skirtingose konstrukcijose, įvairiomis eksploatavimo sąlygomis gyvavimo trukmè nevienoda, todel medžiagų ilgaam- 
žiškumo vertinimas taikomas konstrukcijoms ir technologiniams režimams.

Kadangi statybinių elementu (sistemų) darbas be gedimų negali būti neigiamas, tai egzistavimo bendras trukmès pasiskirstymas bus normalus su tankiu $f(t)$, apskaičiuojamu iš formulès [2]

$$
f(t)=\frac{C}{\sigma \sqrt{2 \pi}} e^{\frac{-\left(t_{i}-\bar{t}\right)^{2}}{2 \sigma^{2}}} .
$$

Čia $t_{i}$ - i-ojo elemento (sistemos) bendra eksploatavimo trukmè (amžius) metais (mènesiais); $\bar{t}$ - vidutiné pasirinktinè reikšmé arba matematinè elemento (sistemos) gyvavimo trukmès tikimybè metais (mènesiais); $\sigma$ - atsitiktinio laiko $t_{i}$ vidutiné kvadratiné paklaida nuo vidutinès gyvavimo trukmès $\bar{t} ; C$ - kuris nors pastovusis dydis, nustatomas iš statistiniu lentelių.

Pagrindiniai parametrai, kuriuos būtina kontroliuoti, kad būtų palaikoma pastato normali būklè, yra: konstrukcijų bendrasis ir vietinis stipris; pastatų erdvinis standumas; bendrosios ir vietinès deformacijos; atitvarinių konstrukciju elementụ issotinimas drégme; metalinių sujungimų tarp surenkamuju konstrukciniu elementų ir inžinerinių sistemų, taip pat laikančiuju metaliniu konstrukciju korozija; atitvarinių konstrukcijų elementų sujungimų oro ir drégmès skvarbumas (stambiaplokščiuose ir stambiablokiuose statiniuose); oro drégmès skvarbumas tarp langu stakty ir sieny plokščių; atraminių dalių būkle ir jų aptaisymas; stogo dangos, karnizų, balkony, latakų ir nuotakụ būklè, pastatụ fasadu, pamatų apdaila, sienų, taip pat medinių konstrukciju hidroizoliacija, deformacijos siūliụ būklè ir darbas, sanitarijos įrenginių, elektrotechninès ir kitos inžinerinès ịrangos būklè bei montavimo tikslumas, šiluminis režimas, patalpu uždujinimas, ventiliacijos būklè, apšviestumo lygis.

Skirtingai nei pramonès gaminiams, kuriems daugelio patikimumo rodikliụ lygis gali būti nustatytas trumpalaikiais bandymais gamykloje, gyvenamuju pastatụ patikimumo rodikliai gali būti nustatyti tik juos masiškai eksploatuojant.

Informacija apie pastatụ patikimumą - daugiapusé, bet jos pagrindinis turinys turi jungti duomenis apie pažeidimų ir gedimų pobūdị: jụ atsiradimo sąlygas, priežastis ir atsiradimo laiką. Ekonominiam j̨vertinimui būtina žinoti, kokius padarinius sukelia konstrukcijų ir elementu netinkamumas. Taigi informacija apie pastatu patikimumą yra kompleksiné techninè-ekonominè charakteristika.
Būtina ịvertinti tinkamumo, gedimų ir ribiniu būsenų kriterijus. Šiam tikslui sudaromas parametrų sąrašas, nurodant jų leidžiamų ribų pokyčius, laikantis normy reikalavimų: išskirti techninius parametrus, nustatančius bendrajj pastato darbingumą ir tolerancijas, kurių viršijimas atitinka gedimą ir ribinę būseną; išskirti higieninių parametrų aibę, apibūdinančią patalpų aplinką, mikroklimatą. Stebejjimų atranka turi laiduoti patikimus rezultatus. Bendruoju atveju objektų kiekis skaičiuojamas iš fromulès

$$
n=\frac{t^{2} \cdot v^{2}}{\varepsilon^{2}} .
$$

Čia $t$ - tikimybès rodiklis; $\varepsilon$ - tikslumo rodiklis; $v$ variacijos koeficientas, lygus $\pm 100 \sigma / \mu ; \sigma$ - vidutine kvadratinè duomenų paklaida nuo vidutinès aritmetinès reikšmès; $\mu$ - vidutinè aritmetiné visu duomenu rodiklių reikšmè.

Tikslumo rodiklis - vidutinè klaida, išreikšta procentais nuo vidutinès aritmetinès reikšmès

$$
\varepsilon= \pm 100 /(\mu \sqrt{n})^{.}
$$

Tikimybès rodiklis $t$ priklauso nuo gaunamo rezultato numatytos tikimybès patikimumo ir imamas 1,96 , kai $P=0,95$ (bendrai išankstinei reikšmei); 2,56, kai $P=0,99$ (pakankamas statinio konstrukciju ir elementy patikimumo kriterijus); 3,29, kai $P=0,999$ (maksimalusis griežtumo kriterijus).

Iš tikimybių teorijos aišku, kad kai bet kuris teiginys apie vidutinę reikšmę ir kurią nors atsitiktinio dydžio dispersiją sutampa su reikalavimais, tai ji paklūsta normaliam pasiskirstymui. Pakankamas statistikos duomenu kiekis apie keliolikos elementy gyvavimo trukmę patvirtina šią būklę. Vidutinè pasirinktinè gyvavimo trukme $\bar{t}$ apskaičiuojama iš formulès

$$
\bar{t}=\frac{1}{h} \sum_{i=1}^{n} t_{i} .
$$

Čia $t_{1}, t_{2} \ldots t_{n}$ - vienatipių $n$ elementų kiekio, eksploatuojamu panašiomis sąlygomis gyvavimo trukmès aibė.

Pasirinktinè vidutinè kvadratinè paklaida skaičiuojama iš formulès

$$
\alpha=\sqrt{\sum_{i=1}^{n}\left(t_{i}-t^{-}\right)^{2} / n-1} .
$$


Iš (9) formulès matyti, kad normalus pasiskirstymas nustatomas dviem parametrais $\bar{t}$ ir $\sigma$. Nesunku apskaičiuoti normalini dydžiu pasiskirstymą intervale, lygiame $\sigma$.

\section{Pastatų ir konstrukcijų susidévẻjimo rodikliụ ịver- tinimas}

Irimo procesų daugdara, pastaty konstrukcinis sudetingumas ir grynai techniniai sunkumai matuojant kai kuriuos pastato techninès būklès bendrojo ịvertinimo parametrus yra apytikriai $( \pm 15-20 \%)$ [1]. Tuo pat metu skirtingiems konstrukciniams elementams vykstančių suirimo procesų aibę (neatsižvelgiant $i$ ju prigimtị) galima apibūdinti vienu atsitiktiniu dydžiu, kuris šiuo atveju išsamiai aprašo techninę būklę. Jeigu $\xi$ yra atsitiktinis dydis, apibūdinantis susidèvejjimą kažkuriuo periodu, turintis vidutinę reikšmę a ir dispersiją $\sigma^{2}$, tai tikimybè, kad nustatytas dydis mažesnis už kažkurị skaičių $x$, gali būti išreikšta tokia forma:

$$
P\{\xi<x\}=F\left(\frac{x-a}{\sigma}\right) .
$$

Čia $F$ - nežinoma pasiskirstymo funkcija, kurios charakteristikas reikia surasti.

Imama, kad susidèvèjimas $\xi$ prasideda nuo statinio atidavimo naudoti momento, jeigu susidevèjimas viršys kažkurią ribą $\theta$. Šiuo atveju gedimo tikimybė lygi

$$
P_{g e d}=P\{\xi>\theta\}=1-F\left(\frac{\theta-\alpha}{\sigma}\right) .
$$

Galima tai perrašyti

$$
P_{\text {ged }}=1-F\left(\frac{\theta / \alpha-1}{\sigma / \alpha}\right)=1-F\left(\frac{\alpha-1}{\beta}\right)
$$

ir matome, kad praktiškai $P_{\text {ged }}$ nepriklauso nuo absoliučiujų $\alpha$ ir $\beta$ reikšmių, o tik nuo jų santykio, kuris yra bedimensis ir gali būti apskaičiuotas bedimense tikimybe $P_{\text {ged }}$. Iš tikrụjų skirtumas $\theta-\alpha$ neturi fizines prasmès, kadangi nei $\theta$, nei $\alpha$ nèra žinomos fiziniu dydžių reikšmès. Jeigu dydį $\theta$ imsime kaip $100 \%$ susidèvejimą, tai $\alpha / \theta \cdot 100 \%$ apibūdina vidutinị susidèvèjimo procentą nagrinèjamuoju periodu. Kuo mažesnis šis procentas, tuo didesnis skirtumas $\theta / \alpha-1$ ir kartu mažesné gedimo tikimybè tuo periodu.

Imame, kad $\xi_{1}$ - susidevejimas pirmaisiais eksploatavimo metais, $\xi_{2}$ - antraisiais ir t.t., $\xi_{\mathfrak{n}}$ $\mathrm{n}_{\mathrm{n}}$-aisiais metais. Tada susidevejjimas per $\mathrm{n}$ metų su- darys $\sum_{i=1}^{n}$. Manysime, kad dydžiai $\xi_{1}, \xi_{2}, \ldots \xi_{\mathrm{n}}$ nepriklausomi ir vienodai pasiskirstę (fiziškai tai reiškia, kad susidèvejimas eksploatavimo metu vyksta statistiškai tolygiai), vidutinis susidèvejimas per metus sudaro $\alpha$ ir jo dispersija $\sigma^{2}$. Šiuo atveju vidutinis susidèvèjimas per $\mathrm{n}$ metu yra $n \cdot \alpha$, jo dispersija $n \cdot \sigma^{2}$, o suminio susidèvejimo pasiskirstymas per $n$ mety išreiškiamas taip:

$$
P\left\{\sum_{i=1}^{n} \xi_{i}<x\right\}=F_{n}\left(\frac{x-n \cdot \alpha}{\sigma \sqrt{n}}\right) .
$$

Čia $F_{n}$ - nepriklausomų, vienodai pasiskirstančių dydžių sumos pasiskirstymo funkcija.

Gedimų tikimybẻ per $n$ metus išreiškiama

$$
P_{\text {ged }}=1-F_{n}\left(\frac{\theta-n \cdot \alpha}{\sigma \sqrt{n}}\right),
$$

o $n$-aisiais metais nuo eksploatavimo pradžios gedimu tikimybé

$$
P_{n}=F_{n-1}\left(\frac{\theta-(n-1) \alpha}{\sigma \sqrt{n-1}}\right)-F_{n}\left(\frac{\theta-n \cdot \alpha}{\sigma \sqrt{n}}\right) .
$$

Pakeitę lygties dydžius santykiniais dydžiais, gausime:

$$
P_{n}=F_{n-1}\left(\frac{\alpha-(n-1)}{\beta \sqrt{n-1}}\right)-F_{n}\left(\frac{\alpha-n}{\beta \sqrt{n}}\right) . *
$$

Čia $1 / \alpha \cdot 100 \%=\alpha / \theta \cdot 100 \%$ imamas kaip vidutinis kasmetinis susidèvejjimo procentas; $\beta=\sigma / \alpha$ kasmečio susidèvejjimo variacijos koeficientas.

Kadangi $\xi_{1}, \xi_{2} \quad \ldots \quad \xi_{n}$ reikšmès turi vienodą pasiskirstymą, tai per jo momentus galima išreikšti ir ju sumos $F_{n}{ }^{*}$ pasiskirstymo funkciją. Dydžiai $\alpha$ ir $\beta$ apibūdina pirmaji ir antrajji kasmčio susidèvejimo pasiskirstymo momentus. Pridejus jiems asimetriją $\gamma$ ir ekscesą $\delta$, galima bet kurioms keturiy dydžiu reikšmèms $\alpha, \beta, \gamma, \delta$ apskaičiuoti tikimybę $P_{n}$.

Šios teorinès tikimybès $P_{n}(\alpha, \beta, \gamma, \delta)$ yra metinio susidèvejimo keturiu parametru funkcijos. Surinkus gedimy statistiką, galima apskaičiuoti kasmečiu gedimy dažnumą arba empirinę gedimy tikimybę $\widetilde{P}_{n}$. Parinkus parametrų reikšmes ir palyginus $P_{n}$ ir $\widetilde{P}_{n}$, galima patikrinti hipotezę apie tai, kad nagrinejamas modelis adekvatus procesui, vykstančiam tikrovèje. Labiausiai tinkamas tokiam tikrinimui yra $\chi^{2}$ kriteri- 
jus. Parametrai parenkami taip, kad būtụ galima minimizuoti dydi $\chi$

$$
\chi^{2}=\sum \frac{\left[P_{n}(\alpha, \beta, \gamma, \delta)-\widetilde{P}_{n}\right]^{2}}{P_{n}(\alpha, \beta, \gamma, \delta)} .
$$

Gauta $\chi_{\text {min }}^{2}$ reikšmé lyginama su $\chi_{k r u .}^{2}$, ir jeigu $\chi_{\text {min }}^{2} \geq \chi_{\text {kris, }}^{2}$, tai hipotezè atmetama. Priešingu atveju modeli galima naudoti.

Kai mūsų atveju atsitiktinio dydžio gaminio gyvavimo trukmei galimas normalus pasiskirstymas telpa intervale $\bar{t}-3 \sigma \leq t_{i} \leq \bar{t}+3 \sigma$, tai normatyviniai duomenys apie konstrukciju arba sistemų vidutinę darbo trukmę turi būti papildyti vidutiniu kvadratiniu atsitiktinio laiko $t_{i}$ nuokrypiu nuo vidutines gyvavimo trukmès $\bar{t}$. Labai svarbu turèti gyvenamuju pastatu elementu ir sistemų normatyvinę gyvavimo trukmę, kadangi tokiu pagrindimu šiuo metu nèra [1].

Normalaus eksploatavimo periodu konstrukcijos (sistemos) turi atsigaminti (net pakeičiant) atsiradus gedimui, ir būtinas konstrukcijos pakeitimas arba atstatymas laiku, net jeigu ji ir nesugedo, normalios eksploatacijos periodo pabaigoje. Normalios eksploatacijos periodui pasibaigus yra intensyvus susidevejimo ir senejjimo, taip pat inžinerinių sistemy reguliavimo pradžios bei palaipsnių gedimų srauto, atitinkančio laiko momentą $t_{i}=\bar{t}-3 \sigma$, augimas.

Šie susidèvéjimo nulemiami gedimai konstrukcijose ir inžinerinèse sistemose yra negrižtamu palaipsniu pažeidimy kaupimosi rezultatas veikiant apkrovoms ir poveikiams, t.y. daugeliui atsitiktinès prigimties veiksnių. Žinoma, kad palaipsnius gedimus galima prognozuoti bei pašalinti, todèl juos galima valdyti sudarant planinių remonty sistemą. Palaipsniai gedimai, aprašyti normaliu pasiskirstymu, neịeina ị paprasto srauto sąlygas, kadangi čia visu pirma nèra stacionarumo, nes laikui bègant konstrukcijų (sistemy) parametrai progresuojančiai kinta.

Tokiam sraute pasireiškia poveiksmis, kadangi parametro, užfiksuoto tam tikru laiko momentu, reikšmé priklauso nuo to, kiek daug šis parametras jau pakito nuo nominalios reikšmés, fiksuotos prieš tai. Poveiksmio buvimo faktas ir leidžia tiksliai prognozuoti palaipsnius gedimus.

Srauto stacionarumas reiškia, kad tam tikro skaičiaus ivykių atsiradimo laiko intervalas ilgiu $t_{i}$ nepriklauso nuo to, kur yra laiko ašyje $t$ šis intervalas, bet priklauso tik nuo intervalo ilgio. Aišku, kad didesnį intervalą atitinka vidutiniškai didesnis îvykių skaičius. Stacionarumo sąlyga gedimų srautui pa- prastai nepastebima nei i̊dirbio, nei konstrukciju (sistemos) "masinio senéjimo" periodais.

Poveiksmio nebuvimas reiškia, kad îvykiu srauto vyksmo pobūdis po bet kurio laiko momento $T$ nepriklauso nuo to, kaip srautas "tekejo" iki to momento. Matematiškai išreiškiama, kad sąlygine $\mathrm{k}$ ivykiu (gedimu) atsiradimo tikimybė laiko intervalu $\left(T, T+t_{3}\right)$ apskaičiuota laisvai spejant apie iqvykiu atsiradimą iki šio intervalo lygi îvykių atsiradimo besąlygiškai tikimybei šiuo intervalu, t.y.

$$
P_{K}\left(t_{i} / T\right)=P_{K}\left(t_{i}\right)
$$

Čia $t_{i}$ - laiko intervalas.

Ivykių srauto vienkartiškumas reiškia, kad per labai trumpą laikotarpi $\Delta t$ maža tikimybè atsirasti dviems ar daugiau îvykių. Tai galima užrašyti:

$$
\lim _{\Delta t \rightarrow 0} \frac{P_{>1}(\Delta t)}{\Delta t}=0
$$

Čia $P_{>I}(\Delta t)$ - daugiau kaip vieno îvykio (gedimo) atsiradimo tikimybe laikotarpiu $(t, t+\Delta t)$.

Aukščiau nurodytos savybes: srauto stacionarumas, poveiksmio nebuvimas ir vienkartiškumas labiausiai tinka nagrinejjant vadinamajji paprastą îvykių (gedimu, atstatymo ir t.t.) srauta.

\section{Išvados}

Pastatų konstrukciju ir inžineriniu sistemy triju egzistavimo periodų nagrinèjimas leidžia padaryti išvadą, kad konstrukcijų ir sistemu patikimumo didinimo bendrojo inžinerinio uždavinio sprendimui turi įtakos: 1) įdirbio periodo gedimu sutrumpinimas; 2) palaipsniu (nusidèvèjimo) gedimų pasireiškimo laiko atitolinimas atliekant technini aptarnavimą ir taikant einamojo remonto priemones; 3) normalaus pastatu eksploatavimo periodo pailginimas; 4) staigiu (atsitiktinių) gedimų atsiradimo galimybių mažinimas iki minimumo normaliuose, pilnaverčiuose elementuose.

\section{Literatüra}

1. А.Г. Ройтман. Деформации и повреждения зданий. М.: Стройиздат, 1987. $158 \mathrm{c}$.

2. Б.М. Колотилкин. Эксплуатация крупнопанельных жилых зданий и их качество. М.: Стройиздат, $1976.85 \mathrm{c}$

3. Б.М. Колотилкин. Надежность функционирования жилых зданий. М.: Стройиздат, 1989. 372 с.

4. Pastatu būklès j̣vertinimas ABC. Vilnius, 1992. $61 \mathrm{p}$.

İteikta 19980216 


\section{EVALUATION OF DEFECTS IN BUILDINGS}

\section{A. Janickas}

\section{S u m m a r y}

The article deals with the peculiarities of non-defective work of residential buildings, their structures and engineering systems. The concepts of the failure and limit state are defined. The causes and influences upon the failure are determined. Possible classification of damages is presented. The author defines that failure is a casual occurrence taking place in the material of the structure the points out that there are object and indirect indications of failure.

The author explains that damages of structures are the result of gradual accumulation of defects under certain loading and factors due to poor quality of production, improper maintenance and design mistakes. The analytical investigations show a close interdependence of damages and expenses for removing them and the influence on the dynamics of redistribution of damages in the period of maintenance. The expressions are suggested for evaluating the possibilities of wear and failure increase. The author motivates the necessity of gathering data pertaining to the failure of buildings, structures and engineering system buildings. The forecast of non-defective work is impossible without the above-mentioned data.

Antanas JANICKAS. Doctor, Associate Professor. Kaunas University of Technology. Dept of Structural Engineering. Studenty 48, 3028 Kaunas, Lithuania.

A graduate of Kaunas University of Technology (formerly Kaunas Polytechnic Institute), 1958. Since 1964 at Kaunas University of Technology. Doctor, 1972. Research interests: industrial buildings and structures, composite structures, structural defects. 